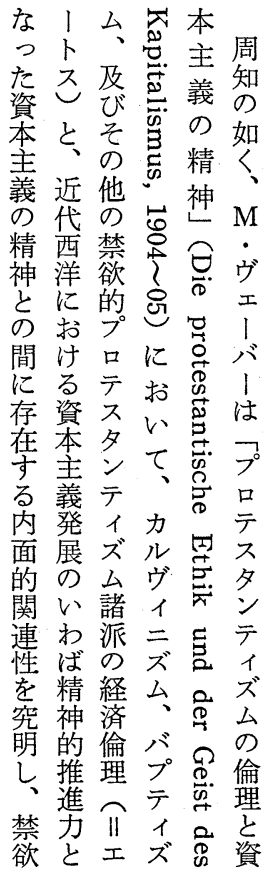

しも宗なな的

て割教問 促 フ み合と題進口 るにの意的テ と多内識影 人面及響 夕 そ見的びをン こ受な分与テ に汀親析え1 はら縁視たズ 相れ関角と厶 対る係を主諸 立。を張派 导そ究っしが るこ明てて資 三でしょ立主 のそう本へ義

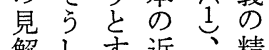
解し卞近、精 架たる帒と神 在学学 万形 乙諸资で成 以説管本 ヴ 対 るを見主エし こ逐の義 |て と 一範 华 ハ 決 を検囲 | 定 見討でと的的
えそべの評てと京れ面本 逆らリくしら発とな小 にの।個よは展す関稿 そ点 $7^{\circ}$ 人 $う$ 浄形る連は れにがのと土態内性 を解形内真の藤を日 答成面る宗相莞検本 国をさ的ヴと違爾討の 一記れ規土商に氏し近 只述資範 | 業つやよ代 家守本とバ資い $\mathrm{R}$ う化 七る主しl 本て の過義て自の必 $\mathrm{N}$ 寸宗 ᄀ程化の身関ず・る教 共でが禁や係しべ先の 同、大欲小を孔ラ学関 体日き的口考十 1 の連 成本く精偉察分の諸性 員の押神一しな所説を 近しが氏て配説の究 と代進出 万、慮をみ明 し化めてのる势検をし てのら来所点な詂取よ の主れな論ささしりう 外体てかをのれ、上 面的きっ吟三て M げす 的条たた味点い:てる 規件かかしをなヴい先 範老とと、指い土る。学 に浄 $、$ 特摘点 1 。 求土ううにとバそ諸 め真点点ヴて、1し説 る宗にとェいヴのての 立老、、るエ所まな 場含答そバ。1説ずか にめ文う、次バと、か はたるいのい!比旦 積日必う所では較本 極本要精論、新しの日 的のの神を旦教た近本 な諸あが発本と場代の 評宗る出展の産合化近 価教こてさ近業のと代 をにと来世代資問浄化 下求をなる化本題土へ すめ指か方との点真 II へる摘っ途浄関灾宗資小 き見したと土係しの本 こ解てにし真をて関主 とにいもて宗論、連義

をはる拘、劣究西性炛原 強消。ら日関乙欧を 調極、続ず本連て歴積と し 的 $W$ 何で性

てなて故は齐ると的圭真 い評、日何消の日に真 る 価本本故極に本評宗 を稿で西的対歴価の 与はは洋にし史し内

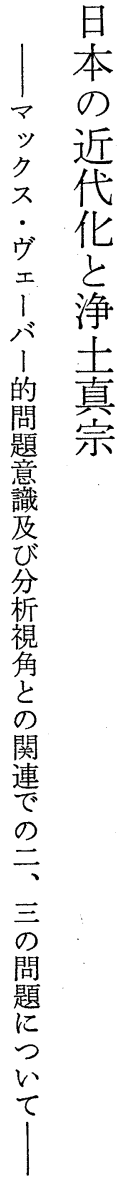

管 
ず、稿の石乗の化わ教はよけにけ式対尔䩗の井出

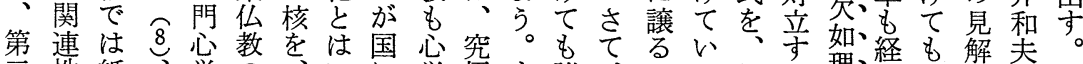

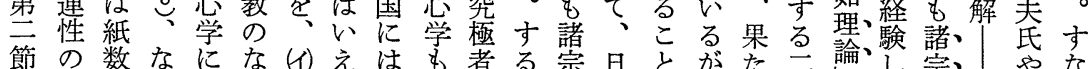
でみのど求加大な仏当にと教本に、しらでな教ら石わ はを関之めの乗、教然対々ののし 日、係いる禅仏が、答卞こな近た、ヴ立京っなり雄、

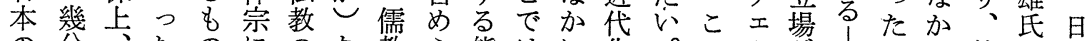
の分、たのにのな教ら態はに化。こI忽昆に第な本

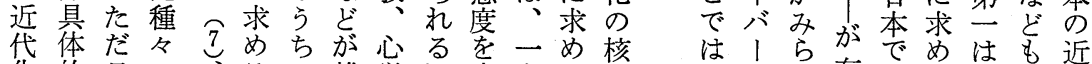
化的旦の、るの雑学意方ると文的れ存はる日指代

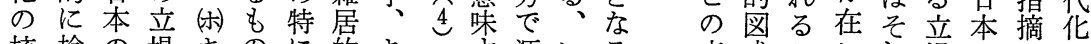
核検の場キのに的キとす源いる 点式こしれ場のしの を討近がリ 浄にリと考る了わべにでとてがで近て核 (价专代見 ス $\sqrt[5]{ \pm}$ 存 ス考。圓ゆき のる化出卜真在卜えし氏る価 大こへさ教 ( ) 宗し教らたの第值 乗々川犼儒にててれが如二体 伀に資る。加教求い簃てっくの系 教と本。でにめる密いてつ立を のど主しも求る故にる仏こ場旦 うめ義か新めもにはを教こを本 ちた华し教るの、日同だでまの のいしなに\&、日本時けいす伝 特。と文求の (口) 本のにでう概統 そそ浄ら め占同の伝他な宗観的

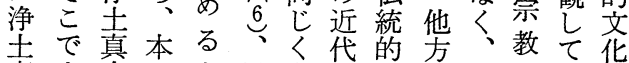
真ま宗小も $\Leftrightarrow$ 大化文で儒とみわ つ解自い欠市代い它 以釈体る如り化るな て出、。し、のよる の来そそて第核う心゙ 考るむしい当をにき 察吕そてるは尔価 を孝々とルが 差い旦こと永国体 しう本のいサの相系 控疑のようン伝対に え問近う、ス 統立 対 等帒にい主的守它 第投华全わ宗文るる 節掛方相る改わう青

立静|勝に治見に

場雄郎了禾解比ま

老 浄氏丶カ期は定ず 極 森真戦ミ実かれ日 的龍宗前 ツ践なる本 に吉とでク的り\&の 支氏近はな立広の宗 持や江ヴ立場くは教

し更商工場加同、史

てに人!加ら意大去

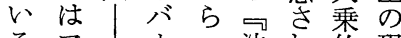
るア、当法れ仏現 ○メレに東然て教象

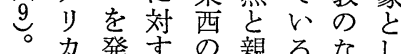

けの表る宗戀よかて

れ $\mathrm{R}$ 乙挑教空うの

ど・た戦改をで特西

छ $\mathrm{N}$ 内的革著あに洋 例心藤なしわる。浄の えラ兆文いた諭とす真ロ ば、氏つう木な宗テ 木な、宗論下おで 下ど戦教文尚ちあ夕 尚が後とを江、るン 江、で経書氏古とテ 氏かは済、加く文、 がか松倫た同はなズ 明る島理原期明すム
身的をバ本論化は所し宗 の条若、のしの、説よに 考件弁自近を核第とう求 二 えを指身代積と云比とめ 評日 幾土し所と的るルしるい 価本分真て論浄にベネた内わ 述宗みを土支きサ場藤ゆ 所 方近 説代 代 内表 化 容的 と 立三浄 諲 説 真

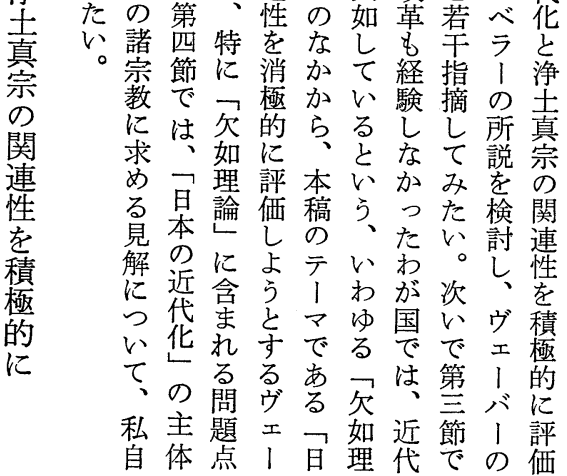




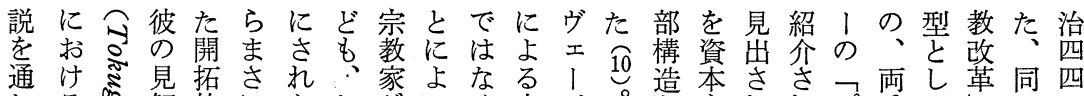

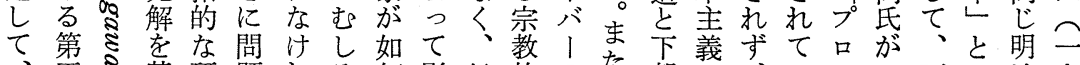
、五々基研題れろ何影信的のた部の势、いテこ西い治九 ま章き本究に汪そな響者承テア構精従なスう洋う四二

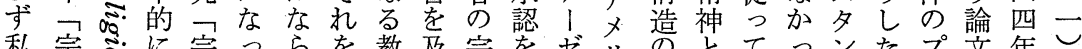
私宗るに宗っらを教及宗をぜリのとてっンたプ文年し は教ミ踏教てな受えほ教通は务機関またテ見口をに年

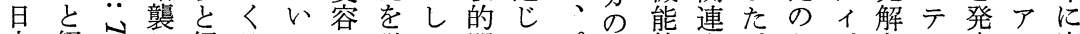

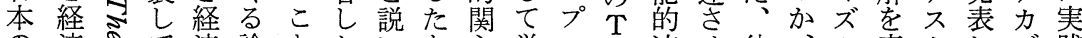
の済のて済論とたいと心営口! 連せ彼、㕕表タしデ践 近しらい倫文を一ていが利テパ関てら彼の明ン、ミ的 代でミる理が意般いう彼追ス「をエの倫しテっッ立

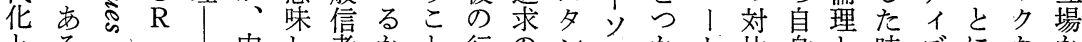

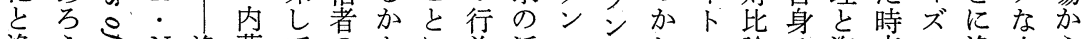
浄 う。 $\mathrm{N}$ 浄藤てのとに為活テズむス論そ資点么浄立ら

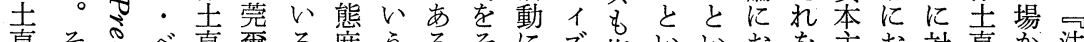

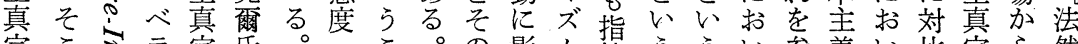

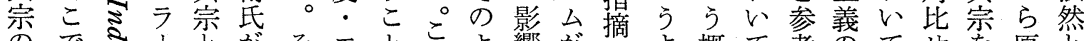

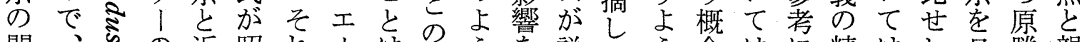
関、令の近昭れ!はこう老説てう念はに精はし旦勝親

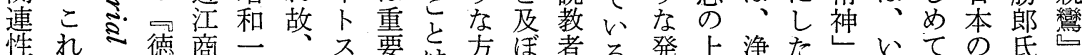
性れこ德商一无要方方者る発上浄たいいての氏心 をらな川人六かこで別向しのよ想で土よはまは宗がを

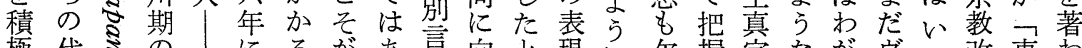

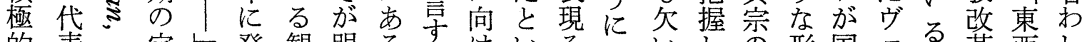

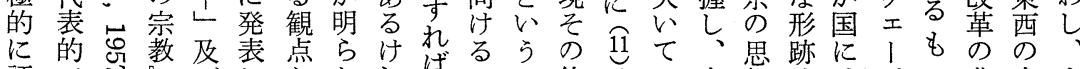

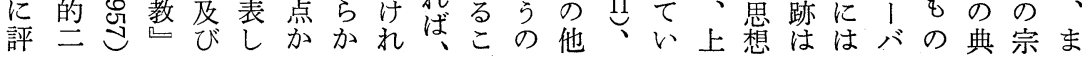

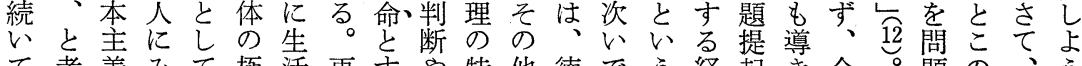

質資商術自単い使值倫都とる有問泉まる響う価 て考義みて極活更すや特他德でう経起き全。題の、う えのらのめのにる誇幑に川、仮済を出くでと研内と こる精れ職て費、と張を店中こ説倫し世冥はし究藤す のの神る業強用こ共は芮舗期こ驾理てな想、ては氏る 近は、こ生度獲のに市藤を以で勿のいい的こおうのの立 江誤つの活の得よ、る氏有降取論一ると世のり浄所場 商りま性で自のう消には滰に甬端。す界点、圭論を

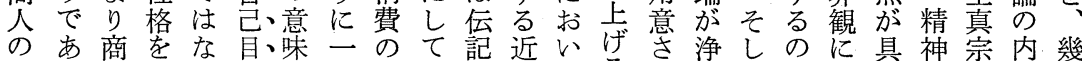
職る人をく的で切面も的江てるれ近ては基体史の容分

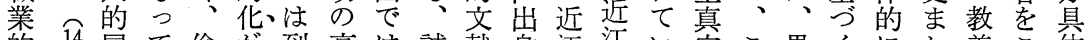
的 $\underbrace{14}_{0}$ 冒て倫驾到享は誠、献身江江い宗こ果くにた義こ体 精。険、理み底楽極実をのよ阔るののた仏如ほがこ的 進心ヴ的ら理をめ真通商り人教問し教何文近にに

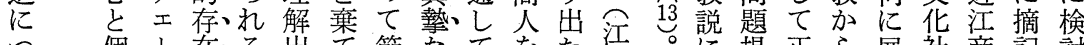
つ個 I 在る出て節なてをた浅。に提正ら展社商記討 い人バと。来て約人解い行商

七的 I 乞まな職を間明う。商商

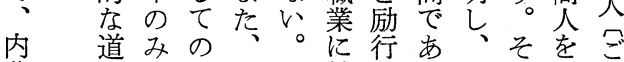
藤 德なそそそ精すっそし称う は にすれれこ進るでこていしい 次関業あ単はると特は彼そう の るに職こにに多られあ よ心賤。処業と求職少のよ气 うな近世生はめ業、経りど に気し江の活、てを、価済三导 由起当は開会人しし 来ので、さ学のてて し背あ如れの経みみ 後乃何て領済るる 基にうない領倫とこ 礎は吕哥る゙域理をと 汀近と済あ属及ずし ら江内的ろ属端た れ商藤勢 $5 し し$ 的 て人民力加てたに 
蓮こ法にいのあ法影な活た自た至れ祖た江は無しかみ 如とのと。でり為響いのの体猟つる親も商彼理、もな よは御どかあ、本安。宗は往漁たと彎の人ら公ましし り、用まくる彼はまつ教、生の共にでののあたれて 発一しらしが二こたま的職に職つにおあも真ろるない しつとずて、人れ大り意羍は業ま、、るる摰う経いる たのか、、後のよき、味生差もり、職て、経なか済が 宗教々そ蓮世言りか蓮付活し、、業はと済浄ら的、す 教理念の如の行出つ如けへ支ま絶と組こな 生的仏宗に信録てたのはのえた対宗々そ理真結織れわ 活進の教あ者でいし御、宗な道者教信れの宗局のにち、

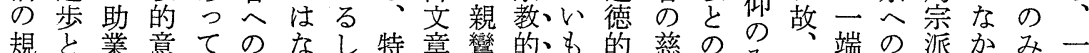

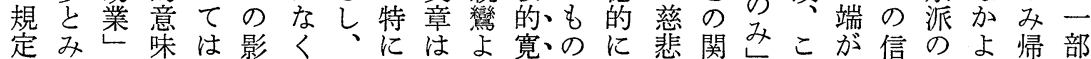
たなと付、響、ま後信り容と卑は連のの浄仰分り属は るすかけ親のまた世徒七にし賤、は连点土と布必せ店

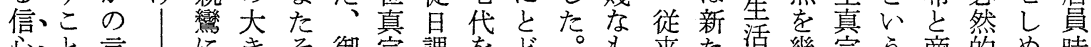
心と言にきそ御宗課をど。も来た活幾宗う商的め時 為が葉職おかれ市势本経まだの悪な弥分忿地人にる代 本、出で業けっ自代宗のたっがと業形弥説宗理輩生この

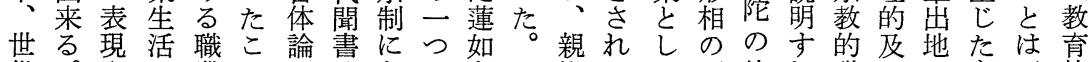
俗。さの業と理はなでをそ彎てて下絶れ職び域も歪的 生否れ宗生は的彼つあまれにい義に対ば業人との曲影 活そる教活い矛のたりた故おたと提的、倫的のと的響 のれ|的のう盾後信、な、商せ示愛浄理条一解解に

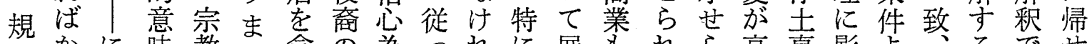

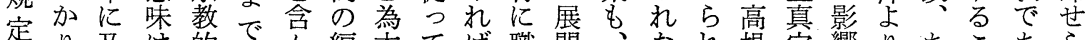
定り及注的でん編本てば職開、なれ揚宗響りあこあら

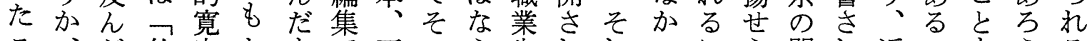
る、だ伀容なもで王のら生れれっにら開れ近いもうる

と経故でる宗共のくにそすし自の唯理は值て諦り王、 共済最は財でに見、おこる感早倫一的止の、と、法、 に倫後欲 $W$ 貨は、落むいでに謝で理の行目観そ改更為、 理に求・学ヴ不ししてのとしあ的道為し念こ称に本、 更と結充ゾ、正てろは注ど慶り過はのな省でざ明の に浄論足么神 | とな俗単目ま喜、程絶集けあのれ治こ 両土とのバのバ荟ら諦に点ら第よ対積れっ浄、維の 者真し経ル賜 ! 欲な中俗はずる怘慈にばて土い新教 の宗て済卜物がといの諦、、こに信悲よな、思わに義 㷌の、領のとプを点最中浄積とは者のりら末想ゆ至は

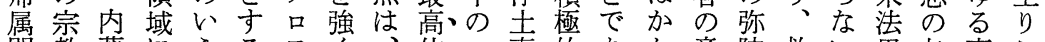

問教藤にうるテく、位一真的あか意陀救い思与真こ江 題的氏と営よス戒真につ宗にるる識の済。想え俗の戸 の職はど利うタめ宗位ににこ。無に本せつはた信時 手業、まのなンて市なあれ更価お願らまそ諦心代 掛倫以っ解意トい教しるっにに值けにれりのきの為を り理上て放味でた義てとて報第のる帰る、助な宗本通

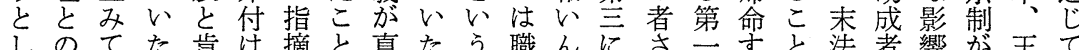
て間きの定はしで面こょ業とはえのるは期で暮確法浄 のたでと遂たあ目とうにすこ救もこ不にあ一立為士 自内よあまによるなでな勤るの済のと可おりっさ本真 利面うるでみう。職㐫軽め意絶せはで能け、はれは宗 利的なっはらなけ業る。度る識対ら人あでるそ、たその 他類近 の似江。いず労ど活更もとあのる無。り間に德でぞ心

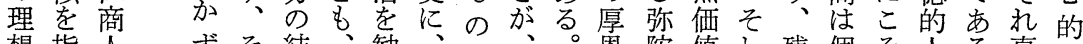

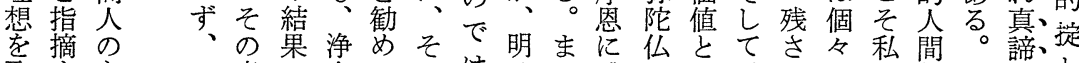

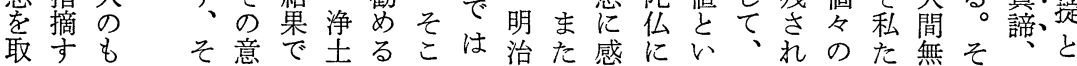
りるつれ昧あ真とでな期謝対うこた倫ち価し俗な 
浄よてのるら勉報の救とをわにてでが農秝れか職上 土う如教禁でにでも済宗真なよ以あ見民次るがら業げ、 真に何え欲あ働あ、支教宗加る下出及に何に生 宗不な肪的るくり現倫的思っ救のたしび故外活次 の当る職態。こ、世理要想た済如とた町べでにながの 師な見業度更とかに的求に。をく認近人ラ考善ら報よ 達利解にもに架つお行とおと強主識江のlるとな恩ら

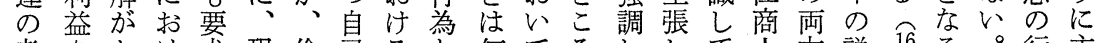

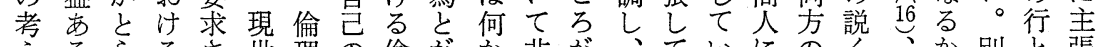
えるらるさ世理の倫がか非が、ていにのく別と張 は、れ労れの的信理不別常、倫いる対昆々と言なし

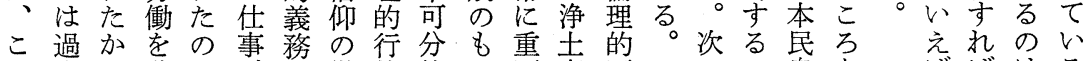

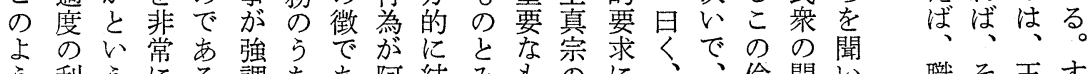
う利うにる。調ちあ阿結みものに、、倫間い な益疑強。さでつ弥びなの第は浄彼理にて むは問調とれもた陀付しと文どはの広み し強驾しこた中加にたしの方真浄意くる ろく生たろ代心ら対よたた創ら宗苦味伝と、

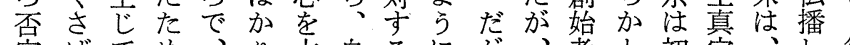
定げてめ、り占自るに䖞、者と初宗、兄彼 的すくに德でめ方与な、蓮い期のかては

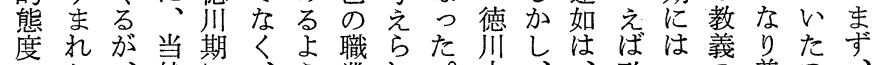

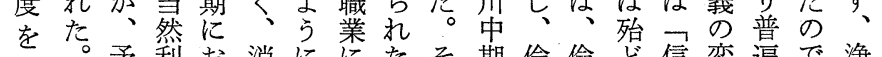
超し想益け費なお娳恩れ期倫倫忘信変遍で浄 えか賉にるにっい恵とな的的意のをな内真

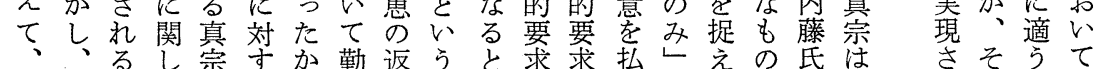

躍成近了社スのに発るあさあをプるし活い江を产でて し 立代し会の組思展そるせさ付口品てのて商与更要利 た立史、碩織势形のなてて記テ本い合の人えにる利 時た考近文学者れ態一うみ、势スにる理具をたっ 代の前代化 $\mathrm{R}$ 力る心っにる内る夕掠点花体取かこ

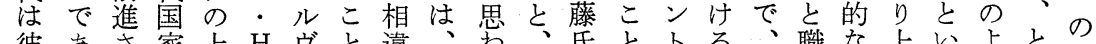

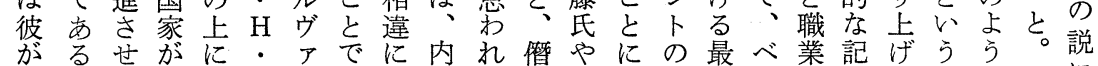
れ。る成大トンある藤る越へとそもラへ述てこなに

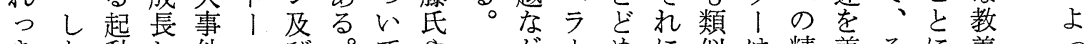

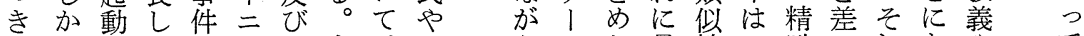

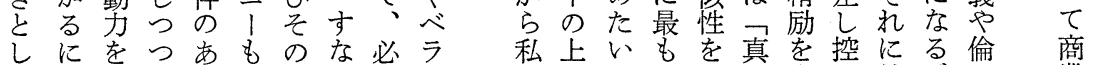

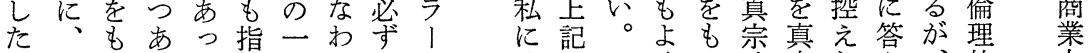

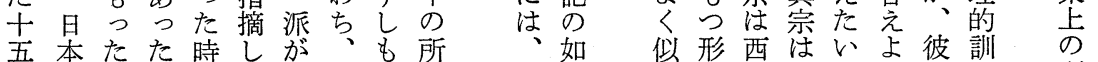
世の歴時代て活ま十説少き態欧直。う㳦利

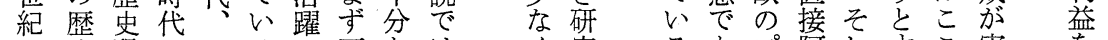

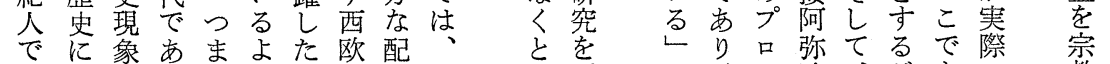
あ眼とりり方十歴慮西学と、テ陀、がもの 教 っをし、、に六史が欧次工主かス仏た、内行的

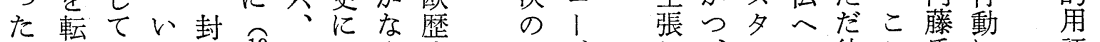

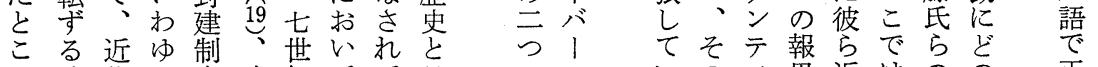

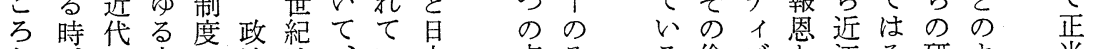

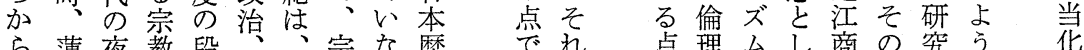

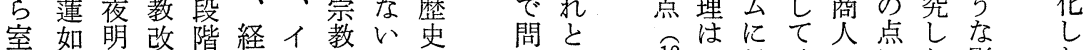

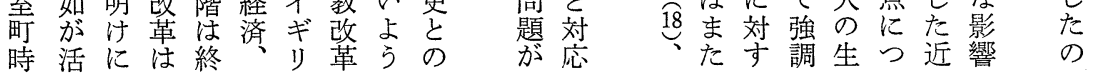


のる両の間えは資究う仏力すた。院のはに鎖秩時代 精も者間のた知本さ残加教と心。取法権いも卞序代の 神ののに精とらのれる。運じ包々締度限わ稀らのでこ 的と間本神これ関て二、動てら的りやがゆにも完あと 要みに質的るる係いつ発曷机に各寺るみ行成るで 素な本的なで如がるは、展。故至宗社宗るおへ。あ はす質な差あく考の、そし突、る諸奉教強れとそり

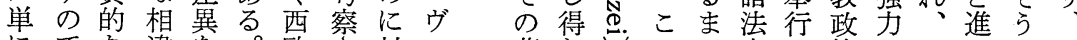
にでな違を。欧さ対土萠た矛ので度に策か以みみそ 営あ差を認すにれし、芽で 20 俗につもつ後、てれ

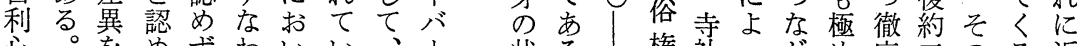
心。をめずわいい、! 状々|権社っがめ底等のる近

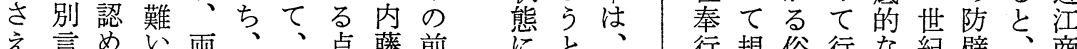

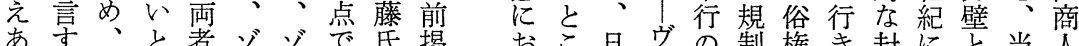
あす、と者ゾゾで氏揭おこ日ヴの制権き封にと当人 れれ全主は厶厶市や論、ろ本土裁さに渡建わし時が ばばく張鼻ババるべ文てののの、定れ従つ政たては最 十烡す然ルルラで封資宗バに、属た治る寛日も 分前なる染トトけ、は殺本教バよ教し時で徳永本華 で者っの連はとれの新し主を|う団、代あ川ので々 あはたに続商ヴど論教てて義萎流て内宗でっ幕鎖はし る資精対专業工文文しし的縮に決部教あた府国西く と本神しる資 は、で産ま展せ、定の集り。政欧活 考主にても本バこは業、っ開しいさ紛団、加政策と躍 え義よ、のと、の浄資、たをめえれ争の宗え治にはし のっヴで産と問圭本、の貝、ばる、活教て注よ反た 資成てエあ業が題真のので指当宗有邪動制、、るる対時 本立支 ! つ資論に宗関は然教様義驾度江世国に代

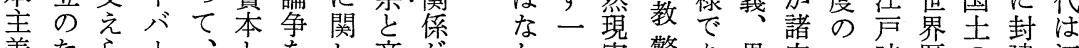

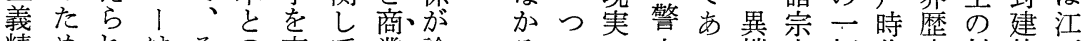
精めれはその交て業論乃のの察っ端寺切代史封的戸

の造一江なちの直吟治揮にをま掛欴心害っか神 一的部商創、はち味氏しおさ見りけ㤩が慮や物てにの 環精生人造そ、にし更てけて出勤離怘挙と詐でそ求起

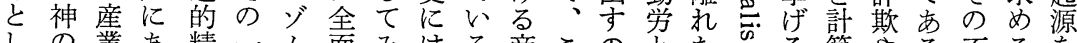
しの業あ精一ム面みはる商このとた号る算やる不るを て所につ神つバ的る宮と業ので節もこ忌の冒と節の前 の有進た、はルな時本思資問あ約のもダ精険い制で期 生者出か換、卜賛、又わ本題るをででヤ神にいの市的 産でしど言江の成ゾ次れのを活重ああ人で満、故る商

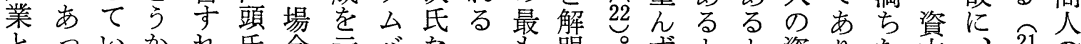
とっいかれ氏合示バなつ的。ずとと資りた本、望の 本たたのばがに导ルど近典しる考き本、泥主資。な 来とが問つ指はわトの江型て 職えめ主合棒義本こか のは、題物摘次けの研商的い 生言しでをしのに所究人なく 産㐫加造て三は論が为を 業難しるりいついにあにので

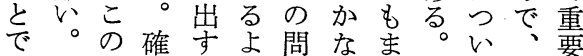
は要こか喜う題いたそてかな 、守とにびにがよヴれのつ鍵

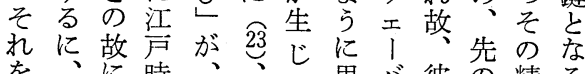
を产時果て思心彼劣精る 支商、代果産て势人号内神す え業彼のた業くれのの藤をの る資ら近し資るる所努氏最に 精本は江て本。説力努多、 神の既商彼にすをにの江よわ に体に人ら必ないも跡頭くが 系創も近要わう、恒発国 莱るつ義理根は主れに 倫。けは的性前義に 理そ、、経乞期の対そ のし近投済忽資合しれ なて代機心怘本理ても 力、産的理原に的、特 に彼業なで吢み発後に

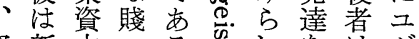
資新本民るきれをはダ 本教に資とでる阻単ヤ 主の比資主でよ此な人 義世し本袁はう亦るるの の俗て主しななる営営 精呙々義: く単々利莉 神的れ我、゙な文活 の禁はすえそるる動 温欲遠艺心 れ投のかの 床つく打障えな 
に精はれずんとこ行にと泥は本次にに名機るるいい 考神、はるずなうおは考棒、主のま説声構と時かて

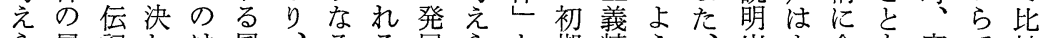
ら属記しは風、るる展らと期精ら出よ合も宮で較 れ性的てむ潮一とよがれいの神なヴ来うわに本あし ると文例しが時貣うあるう段の理エるやず、氏るて 加献外了生の険にり。諺階特由、かく、ぞ。 らてにで自じごにな段しがで徴にバと衰この近残る

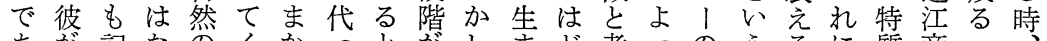

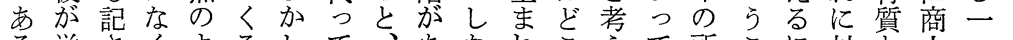

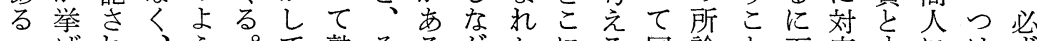
げれ、う。で熟そるがたにる同論と至応すには等 包るて彼でかは慮こと方ので詐意にでっしるるいし

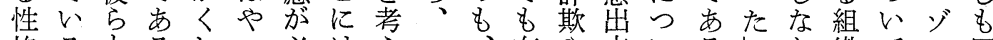
格るもるしつ必はえ一、存や来いる等か織てム同 通極。てて要一ら概要在欺なて。24っやユバ質 りめ近、い定れに守守蕾いは 近でて江商けなのる商るるに。内 江あ合商業なり系。業にと満つ藤 商る理人にい、統交資こ思ちま氏 人。性のおの投と易本の尔たりや

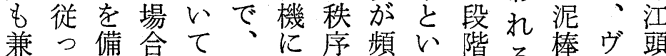

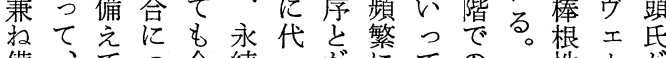

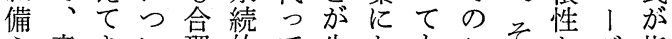
え産きい理的て生なむ。元指 て業てて的な計しり 、文故い! 摘 心資いみ経信算て嫢そで故うがし る本るて営角がく則のあつ息商て よ主こもの必る的なっ近も業い とた商明ルで 記め法治トあ すに、期先と 皮新以に速 肉退し降み断 な嬰い近たす 現守時代見る 象る代的解こ をにの工にと 至資業照は どり本がら許 の、主発しさ よそ義達てれ う義とこ生重要。にかた江の資るるう的㠻みな

せめそ資もにこは要欲本さで华諸が $\mathrm{T}$ 持ゆ国

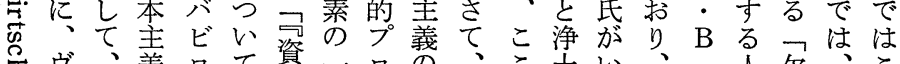

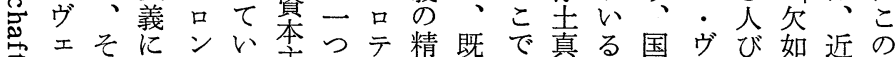

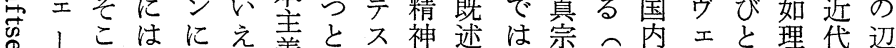

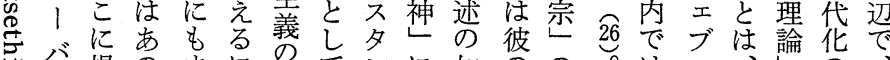

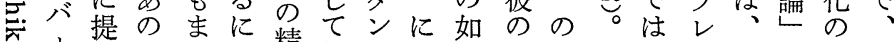
○!起独た過精継テおく所関し大ン国に核第

邑自己自古ぎ神承イ心方説連加塚、外眼核第 そ身たの代なはしでてェをでし久イでをなの

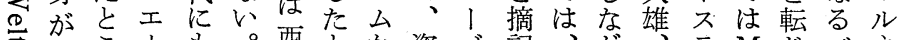
㤩後こ

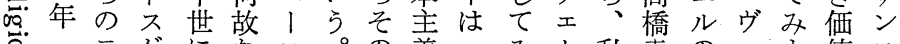
○フテがになロ。の義つみ、私幸の土よ值ス

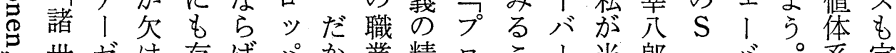
世ゼけ存ばパ架業精口こ1当郎! バ。系宗 当界をて在資的ら倫神テとの面的 $\mathrm{N}$ ! 另教

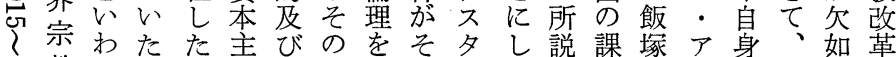
当教ばたた主びのを義当当多し説課塚ア身、如革 の間 27 だ涹メ然自生テう特と三ゼはす経 及経接々が中リの方誕イ。に玄、ンじ立い験 び経接と的者：国力結のにズ注る吉シめ場るし 経済に考 $\vdots$ に的果決あ㕕 経倫証え $\vdots$ もなと定たの 済理明て之資し的っ 倫

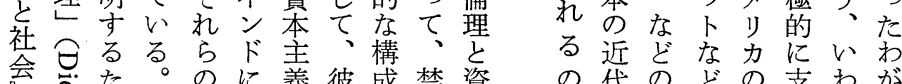
目田二、老とな さ日久タア積いか れ本一ッメ極 う。 


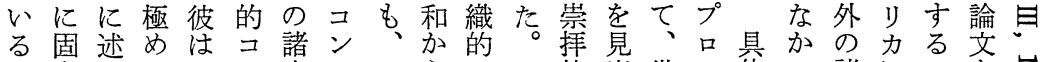

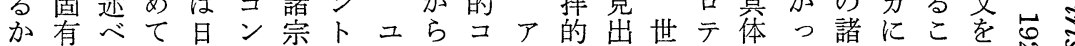
らのる大本卜教口ダもンジもし界不的た地のと書志

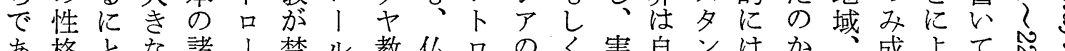

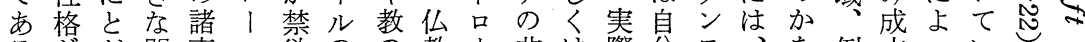
る吕と関事ル欲のの教、非は際分テ、索例立っいい

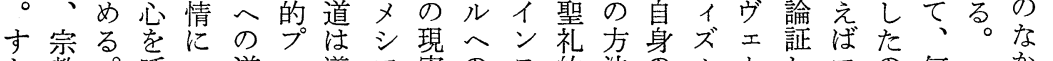
な教。呼つ道口導ア穾のテ的法のム、しアの何つか わ的とぶいをテかの世道り手が地とバよジか故まで

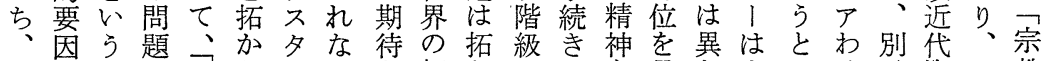

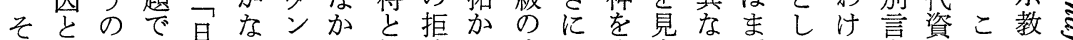
のははあ本かテっ経絶れ魔よ崇定りずててす本れ社

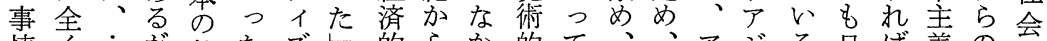

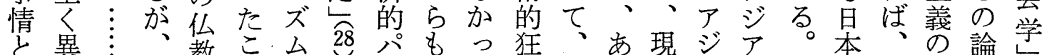

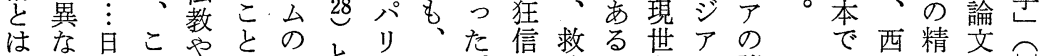

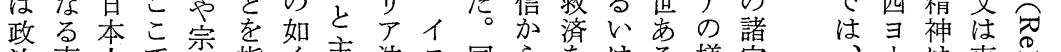
治事人で教指く主法不同ら渗る様宗 的情のは稚摘、張吕ラじは求強い冬教

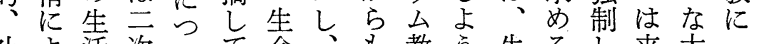
社よ活次いて命、も教う生るし来大っ 会つ態的ていのそ、のに命魅て世衆い 的て菙形度しはる。拿こ決世儒の惑儀に的て 造成の加そ次的はて征の理園的け教つ のさ精もれ、渻服世的で、る禁 封れ精簡自で組 ジ織加界市偶安と欲 建、て神潔体、織了的ら調組つ像心つ的 そ文西西 票. れッヨの がパ 1 諸 ら゙ 及 て ア パ 学 成リび較 立力ア検な し以メ討 る 品

た、に情済っ真比なす行いし気わ教ななはべた律西的 。教し要者た宗較くるかてて分ちのど方大る、的洋性 そなて求宗。と专と敬らはのを人こと法部ととな的格 のい敬に教そいるも虔解以魔生生のはに分い断法な落 色儿虔適でれえここな放悲術みを形お頼のう言の意あ 調西な合あはどとの帰さのを出含式よら諸そし担味る

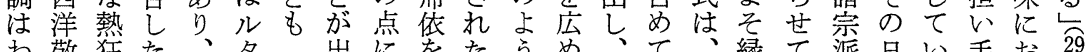

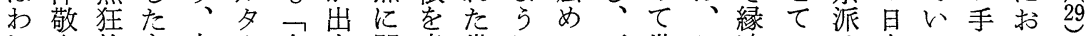
れ虔的も中!合来関意世にた更世た遠いは本るとけと れ主エの産派理るす義俗評のに界だ、る る ののスは級場、的限けなしあ果無間の、文宗いの民、、 い敬タあの合世をり、る信てる底価にでその教て都層そ

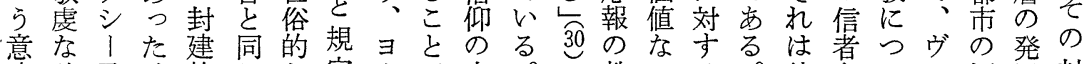

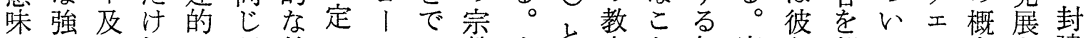
に心びに理禁しロ二教まと䏍と. 無実ら部て1念を建 お情魔ど統由欲てッ切でず主との関際を分、染阻制 け熱術も制にをいパのあ、張そ確心に合的総1 日止こ るをのさむ登るの。善る浄すれ信な俗理に括は本しそ 感受色古れる達。プ業。土るかとも人的は的三でては 情け調代たもさだ口往：真とらいののな極に次はし外 容、七救のせ出生引宗共免う、信生度的全ま国 狆まン済でる次スを專をにれ、無者活に浄に然っ貿 导るだ諭あこいタ拒ら、常の方非圭し存た易 豆こは、的るとでン否阿達浄た種な間法合真か在しを

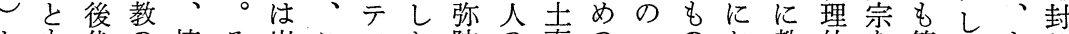
とも代の情そ出こイた陀の真の一の接的を簡なまし 心なと民緒れ来のズが仏自宗手般、㳘な除潔なた込

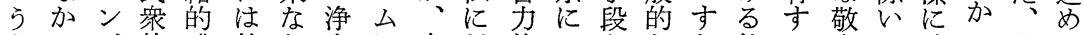
よっズ的感救か土に少対修つとなな仏る虔て述っ自 


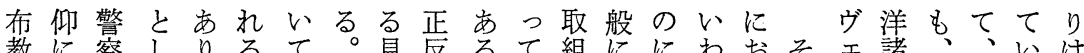

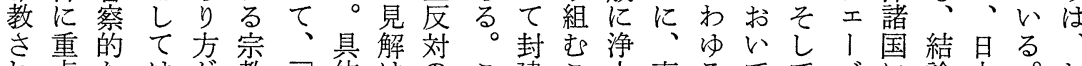
れ点なはが教支体はのこ建こ寘るて、、゙に論本。さ

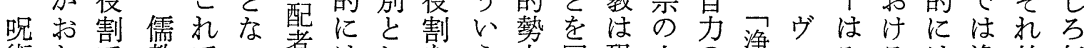
術かで教でっ者はし索う力回現人の浄エみるは浄故気 をれあがあた結、て果点に避害々立圭、なと両土分 排たつ用るこ繥例、た吕協守逃は場孝バし同者真西 斥わたい。と付え今しら力る避最に流、て様の宗洋す しけ。らもは付壮日た考し態の近立流のい間をの节

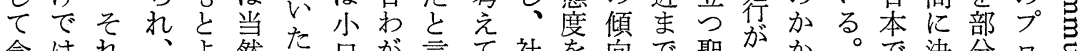

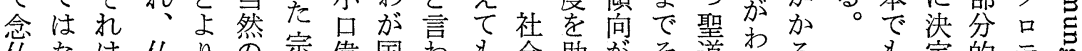
仏なは仏りの宗偉国わす,会助驾そ道がる

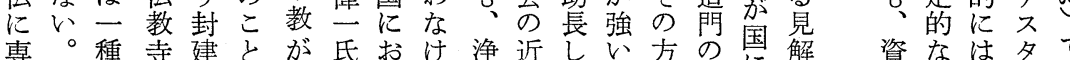

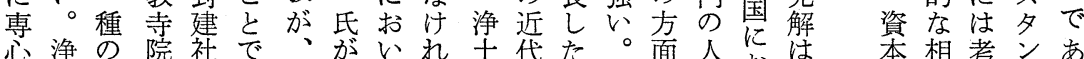

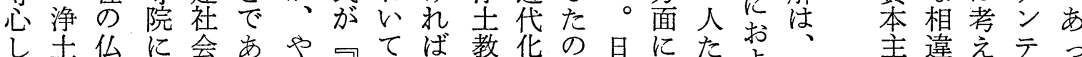

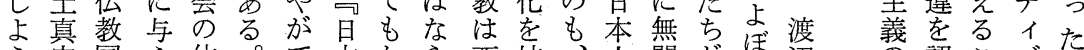
宗国え体。て本加ら西妨、人関がほ辺等認こズた との教ら制江は宗なな欧げ浄が心社し照精めとムう すよ主れを支教りいにた士正で会た影宏神てがにうて

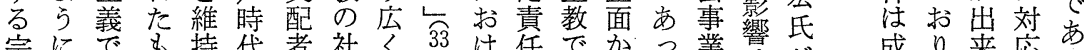

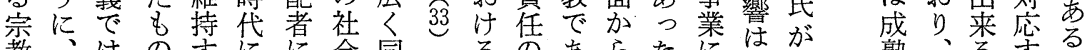

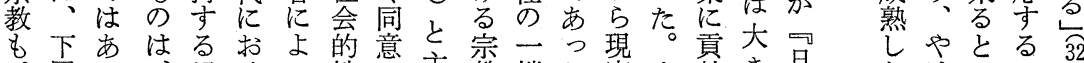

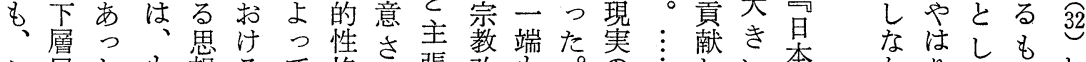

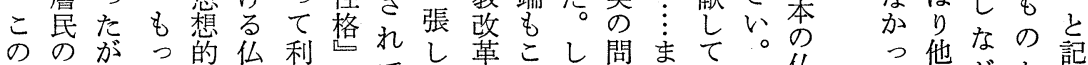

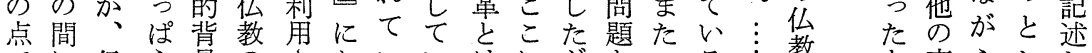

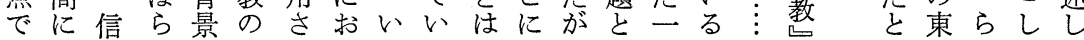

ち騒聞な教己いにゆ如両ス史革不スにおい報をは 全擾:三今背今变キおるそき者夕学と可卜あいる恩規例 国索六こつら革りけ宗れ見のン者封能のるてが感定外 を発号のた近をスる教故解教テに建な態に、如謝すで

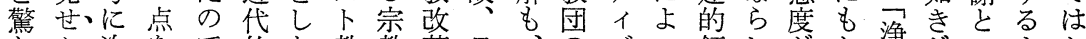

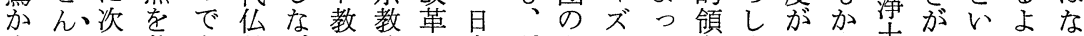
すと、の若あ教がに改な本ヴあムて主め示か真そううか にす、よ午るへら、革るでェりのい制るさわ真れよなっ 至。う敷 36 の、そはもは1方思ろのほ和宗でう教た る若な衍 36 転その、の封バは想い対どてずぱあな説

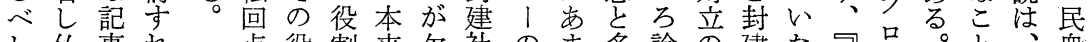

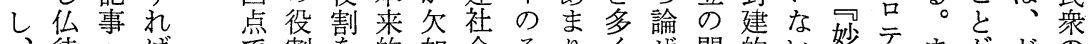

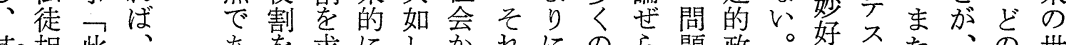
其、相 此 勢、集 度 慶 必可神応 ぎ、て道四 南、事 㷌 北を一二 西、起の八 部ささ 号 六 の、ば令公 会、疾出 盟、雷た年 諸、のる 閏 侯、轟に四 上、く依月 り、がりの も、如 大、中 遙、く、外 に、忽に、新

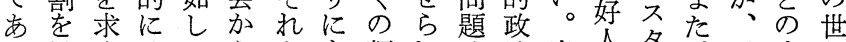
る果めはてらと類れは治当伝多説宗俗 維たら民い近同異悠て点権時伝光中教教的 新吉れ族た代様な点い西力のにテ村さ加倫 期べる宗と社なっをる洋肪社に元れら理 にきべ教考会認てもがと強会はズ氏たも できとえへ識いつ、の加に封㕕肪程生例

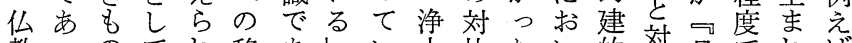
教つのてれ移あ流市比たい的対白でれば のたでのる行る可る真にのて勢毕本あて日 变。な神。期。々に宗おでは妿さ宗るい常

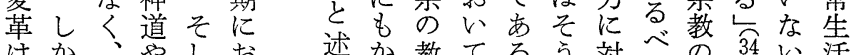

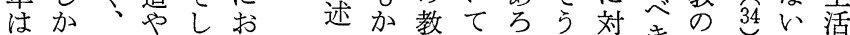

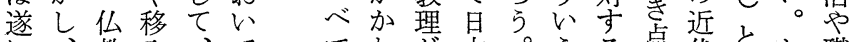

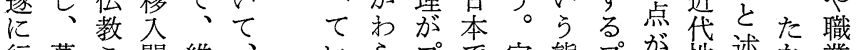
行幕こ間維、、方プで宗態プが性述か業 わ藩々も新いるず口も教度口多地べだ倫 れ仏自な期わ汃、テ歴改をテ分にてか理 


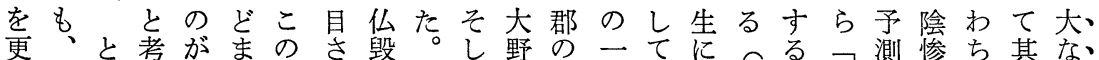

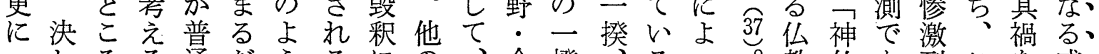
二しろる通だらるにの、今揆、るっ教仏あ烈こを威 歩てでべでけに心゙積仏こ立、四。てこの判りなの避権、 進問、きあで明き極教れ、五年し形れ側然、宗記活を、 め題ヴでっあ瞭も的宗ら坂年言加骸はの然老教事全握、

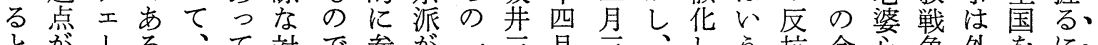

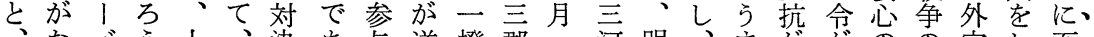
なバう上、決あ与逆揆郡菏明、弯㤎㤎の字し至、 住い! 記共をっしにはの越の治人で驚発忠歴新て ら 谷わの $\underset{0}{39}$ 鬲したた打例一後僧言びもくせ告史聞安ん。

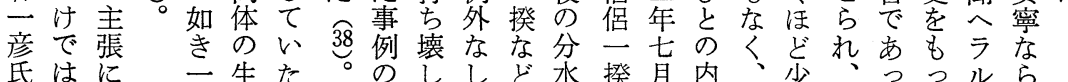
氏はに二生た。のししど水揆月内、少怔っっルら もな代揆活のだ多のに、騒市面幕なこたたドし希

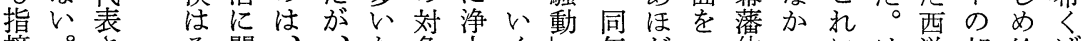
摘。さ简、、な象士く年たう体っにけ洋邦給ば しすれれしたこかと真つ六一らか制た伴れ人訳わ日 てなる 故てかのでさ宗か六 $\bigcirc$ 教ん年こうどのでん本

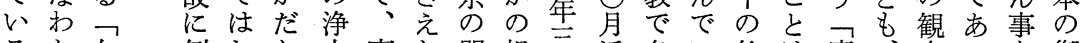
るち穴例む加土真な門根豆浜名、仏注、察っを御

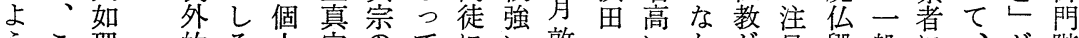
うこ理的ろ人宗のてに敦へ、か加目毁般に、が陛

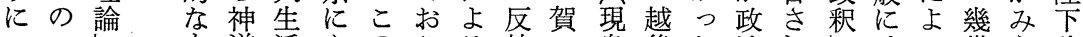
40矢に道活あのりる抗っ島後た治れ沈る世ら此 尔にのをのっ独、も現根相こ支るの維社紀れ事

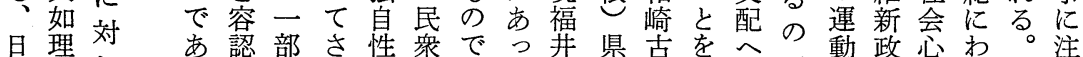

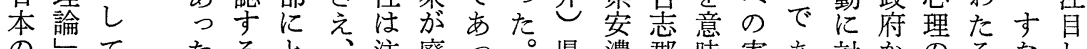

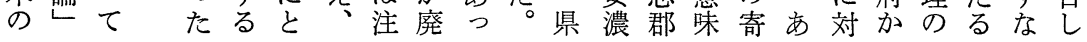

い威も役ナマ従っ思合はの相け会恩そ式に進てううなる近 噴もてな国てり等西加違るにのこ解こ進はと個う化 出ついっナの動、命洋ろ等諸お思で釈のらとと人、は

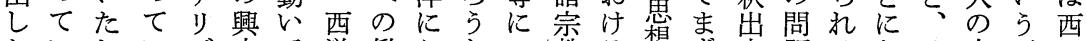

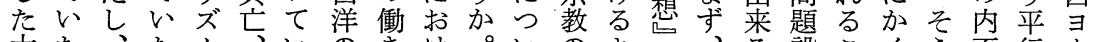
大た、たム、いのきけいい設こくう面行、 衆。歴。の中た経掛るそてそりに第少定と心い的関口

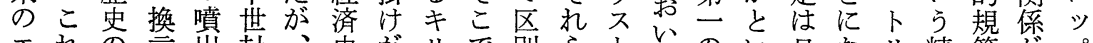
エれの言出封、史がリで別らトてのい日なリ精範がパ ネにあ导や建名や比不守と教指点う本っ神とみの ル反るれ宗制目政較卜第る比の指に疑のたプがしら近 ギし段ば教と的治に教二こ較社摘つ問近のが出てれ代 Iて階、改品に史なのにとし会ていに代か形てのた化 を、聖革、は梳機指に、的てても化、成来禁に、と 結日は権なマ殆実ぬ能摘よそ機るはつのとさな欲も、の 集本聖はど教ど質程と出つの能る、な方いれか的拘平 しの権俗、皇宗的弱比来て比やと鈴が武う推っ 精ら、行 た宗は権常権教にい較る、重思こ杰っを問工た神ず関 あ教俗ににののはも专こその想で宗て、題業に、が、、係 るは権対宗確形社のるとの軽的芯憲い果が化も、出何に 時社を抗教立式会で時は答重内㐫芯る。生の拘て故お

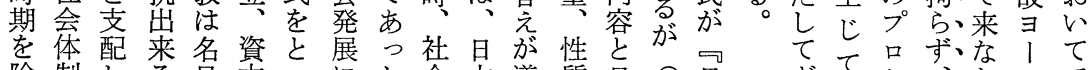
除制しる目本っにた会本導質白 $\widehat{41}$ 日皇てセ、加で

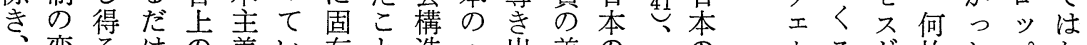
支動ほの歴のた義い有と造宗出差の西社西近黉るが故たパな

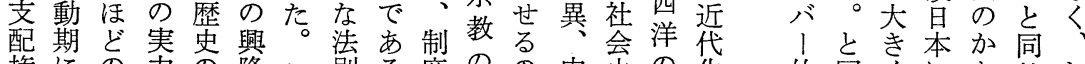
権にの屴の隆口則る度のの内史の化的同くにとじむ 力お権を主や、に。場で容に社と図時押おいしし 
主いて個述受生た加たたち合団っ全内動第目既動者

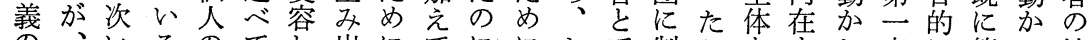
の、以るのてし、出にてににキで制こを守し点に第し地

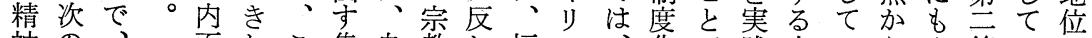
神の、面たこ集自教し福ス、花で践本いら聖節いや とよ第的三れ団然倫て音卜かしあ的質く容権でく役

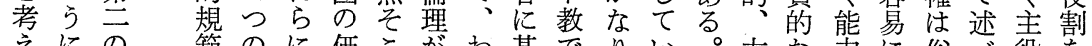
えにの範のに価こがわ基でりい。方な爫に俗心役を た考点 と理随值に儒が等は構るそ法もだ導権たの合 ピえにし㕣順規は教国く聖造道し論のけきに如立法 二てってにし範宗倫の倫権的德て的とで出従く場化 はいいよてを教理宗理がに的、にしなせ属でにす リるて 禁り、い無倫に教生俗異価第倫てくるしあなる

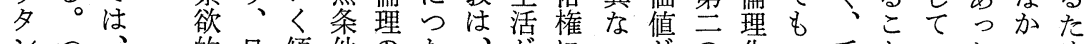

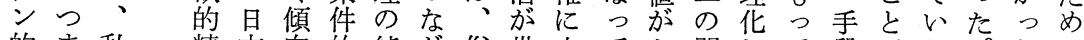
的ま私精本向的純が俗世十てキ関して段でた。要たの なり自神でが、粋る権俗分いリ連てい、㐫。要。権 職、身㤎は強無性世㤎生にたス无いた方る次守特威 業ヴ試生少か批が俗聖活対とト第くの法が、るにを 労工論まなっ判失倫権の抗い教严面にと劣にで徳提 衝、的れくた的わ理をモ出うのに文対しキ、、少供 観バななとにれに圧ラ来こ場指欠してり第日期し

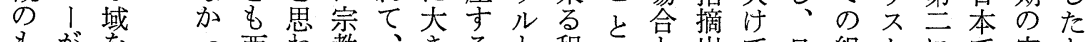
もが孝っ西お教、きると程でと出て日組卜にで宗と つ西出た洋れ的支く程常強で星来い本織教いは教し 、欧るとる態配依強に力あ本るるの理はえ害政て

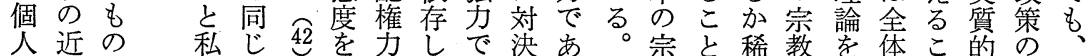

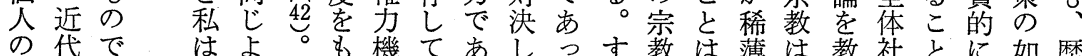
内資は考う以っ構いりてたなの薄社義会はも华 面本なえな上てのた、いがわ場教あ会に拿、名はを

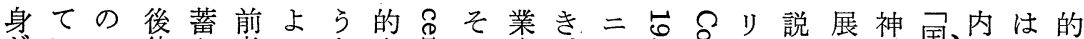

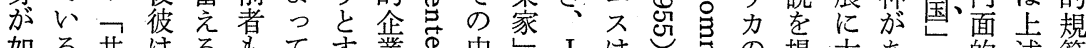

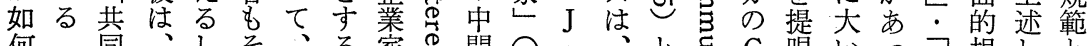

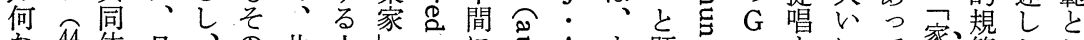

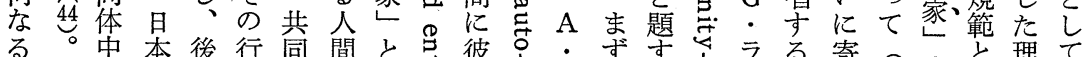

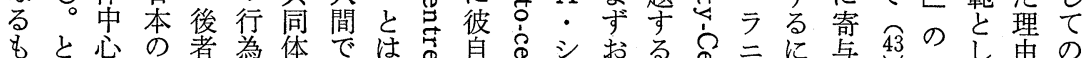

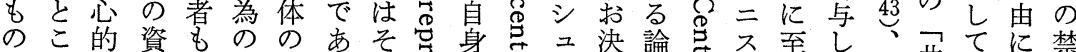

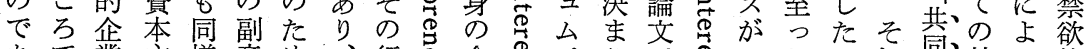
あで業主様産め、行』命尺ぺりでミったのれ命禁り的 つ、家義に物に共為㐓名』１９、旦背でが体、欲困精

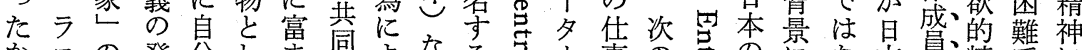

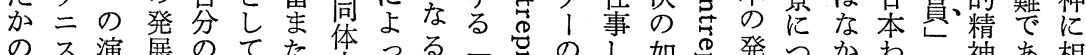

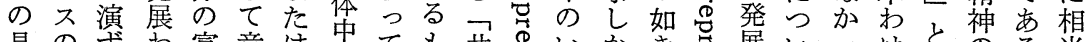

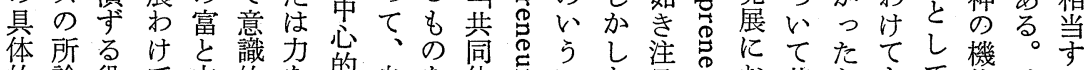

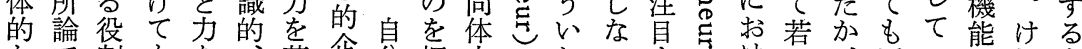
なで割もを蓄業分据中々わい专中季、近のをれも

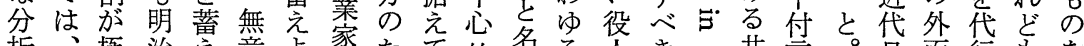

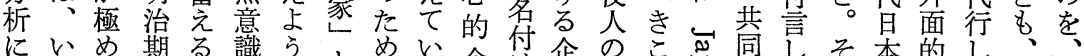

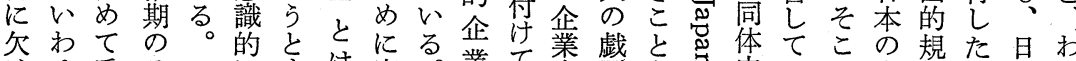

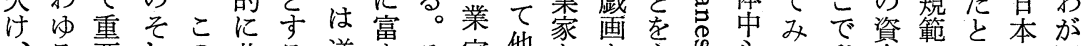
、る要れの共る逆まそ家依をを主令㤁る私本に思に国

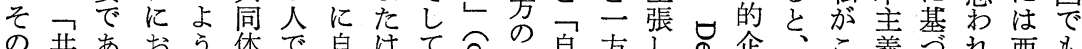

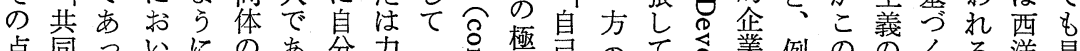
点同っ、にの分力号極芑のて岕業例ののくる洋見 で体たて理富るのを自哥に中極い字家えよ成禁むの出

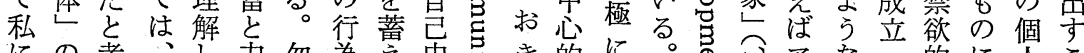

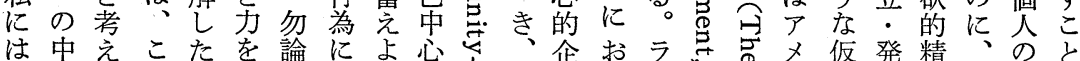


は踏関ツ浄諸角と 日襲連卜土説を資私 本し性を真のも本は のてを当宗なっ主本 近い積てのかて義小 代る極て内少、の稿 化 $\mathrm{R}$ 的き面ら日精で と: にた的、本神は 浄 $\mathrm{N}$ 評。な 紙のし

土・価与関数近及 $\mathrm{M}$ 真べしな連の代び・ 宗 ラよわ性関化そヴ の|らちを係とのエ 関のと、検上宗他 ! 連所す第討た教のバ 性説る三したの論 をを内節よ日関文が 消検藤でう本連で 極討莞はとの性示プ 的し爾日守近をし口 にて氏本る代究たテ しきやの先化明問 加た彼近学等題夕 評。の代の IIよ意ン 価ま見化諸資う識テ 出た解と説本と並 1 来、を浄の主すびズ な第基士み義るに 以严本真に化先分の と節的宗 主でにの ポとの視 理
範精えが理ま恩的故体成国い に神たあ想たは企、でし包さ 基とピつと無無業共あるいとさ

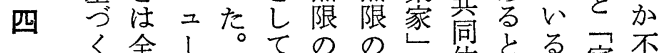
結禁く全 そ要 \& \& と 体考個家満

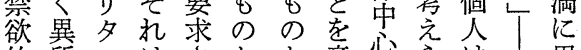

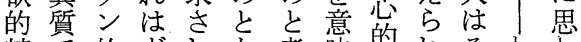
精で的ヴれな考昧的れそわわ 語神あな工精あっ元し企るすがれ でっ職、そたらた㙞|な国る あて業バこのれこ豖| かでが つ労!にでてととでには たい㗢がわ交がにと没家早 とわ観西がるたなは家本 考ばの欧国。かる結かししの えつ\&のに私ら。局っては場 ら共つ近拉利、してたそ合 れ同、代け・文加国かるれ、 る体個資る私れ \&中とと自共 成人本労欲 0 心私心身同 員的主働をの 的は引人体 規義 の離奉国企み意格以 と範の禁れ仕業な味をの しと精欲たとの家しです中 七し 神的無し恩尔て、ち身 のて の倫限て やとい小㤝 外の基理ののつ只さを 面禁礎の奉労家家。なれや 的欲々基仕衝し中そ共をは 規的考礎呍もの心れ同構り

神かいめ源連こな聖しつ記的るを、けさと影味張 よでうる了性とかか権たて述にの浸る、に同ン期・点しす り最のヴ圓をなっつ如いし評でし、よ、事様卜歹 $\mathrm{N}$ ててる 与むは土氏消がたまくたた価、、たう、実なの゙゙・疑きず え早、、と極らとり、と渡宁日り、な、゙役倫そア問たエ らくルバ共的私み宗日は辺る本、中、あ割理れイ点。!

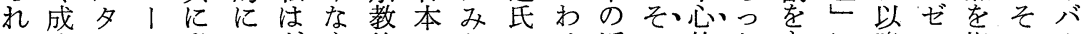
た立、の私しヴす的でなのけ近の、的たすに降ン指し!

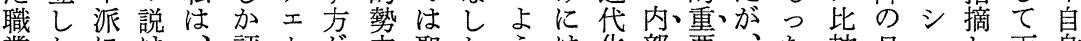
業たには、評、肪力聖たうは化部要、、た較日日二し両身 とのお大ル価バむ怔権くにととに、性し、いむ本タた説を

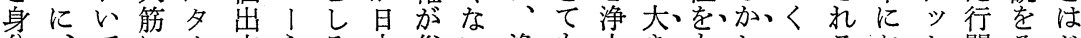

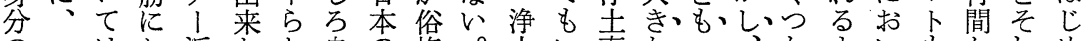

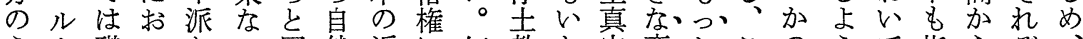
引夕職いとい同然近に何教か宗変た、こ、のうて、指らぞ、 ち、業て浄と様で代比と肪なの化む、れ、重なな摘をれ小 に派観当土考にあ化べな日い関を、の、ら、要、例し既支口 原は念っ真え、るをてれ本。連与、での、なかえてに持偉 則次はて宗る日か妨極ばのだ性え、は、指宗つばい明す新 と第プいと 者本らげめ近がをる、な向教部べるらる しにロたのののでるて第代さ化を、く、運分ラとか先 て各テと間一近あ㗢 無三化り内の、、運動的!こな学中

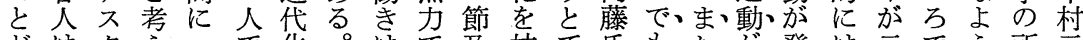
どは夕え—で化。はで及妨て、氏8、たが、発は示でう所元

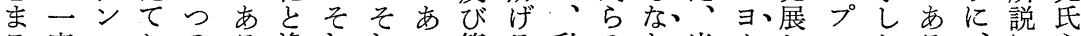

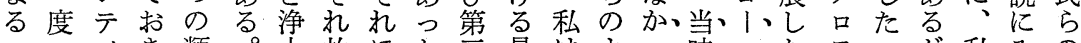
ベっイき類。土故ほた主はよっ、時、ロ、たデが私みの

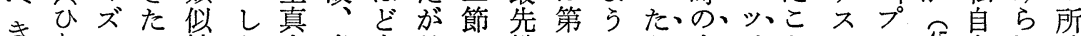

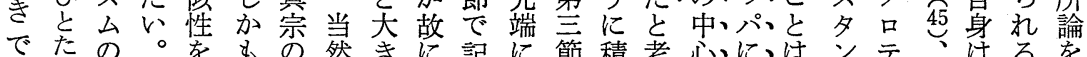

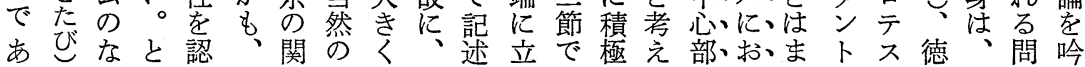


でナ題求し浄か説浄に節経えり、

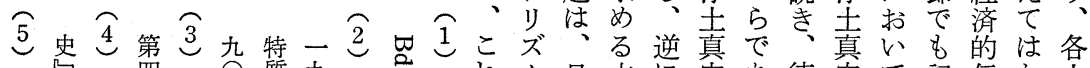

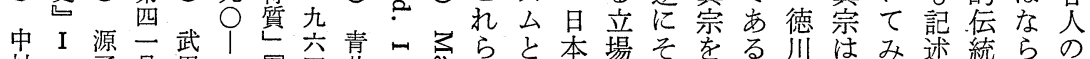

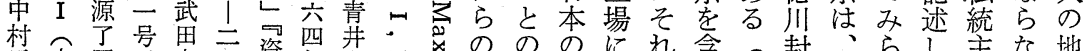
元古圆良无資年和苂学のののにれ含封、らし主な地

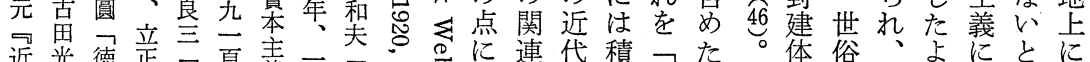

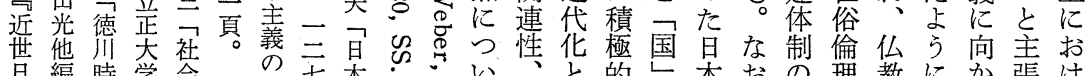
日編時学会思七本・的体おの理教にか張け

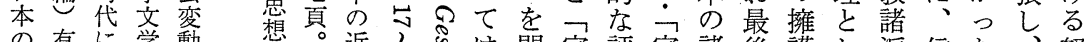
の有に学動算。近?@は問家評家諸後護し派信た、努

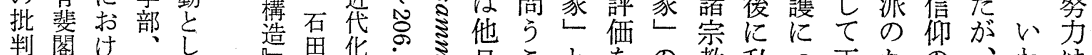

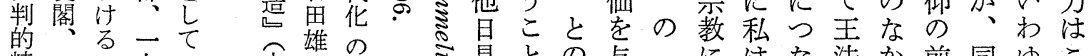

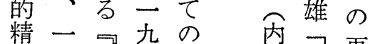
神九近七近田わ再 六代三䒫義唯検 分分思年货蒂国䚺 中年想八に想に思 元四の頁い等惼 選九形参て岩る忍 集頁成照し 波ウ第

第司咅畫工四

等㐼昰店公

巻帒学 九市

春本齐竞解岩

$\begin{array}{llll}\text { 愁 } & \text { 社 } & \text { 学 } & \text { 会 } \\ \text { 社 } & \text { 思 } & \text { 論 } & \text { 年若書 }\end{array}$

一 思 諼 二年扂

な其との与つに注な法加前同ゆこ 体に関え共求、吕為での様るの き的あ連て同め正る本最職に現与 なる性き体る杲現プを業浄存え 考。成見本存ラ早の土秩ら 察し及。員解近秩又く平真序れ ミ委がそとに近序仁成等宗のた ミ試し日れとは帒義立と宗維生 み最本故し消华の礼しい場持活 こ早の、て極の順智たう合の上 少. 紙近私の的主信の考に方の た数代に外な主䒚忩にえも向地 心。化残面評体説儒、的、別位 尽とさ的諲的い教徳開既言の さきお規価条て倫师祖に高枠

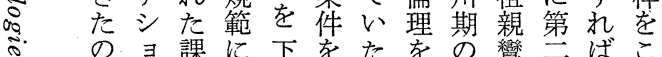

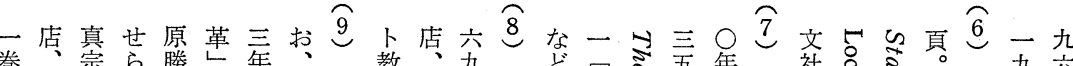

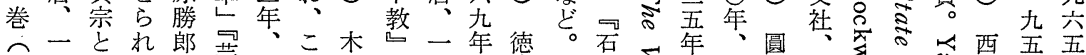

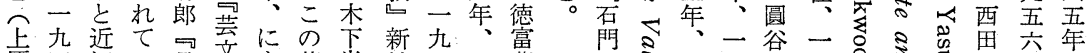
原四江 禄年人の中第載注版年三っ

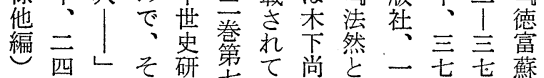
角品机究夲心江親九言峰

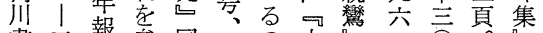
書云報参同京京で李金年兰加 亲拿照館都、尚尾年面明 一頁学だ齐そ江齐七㤵治 九松第内无学势著淵上隅三文 五島盆藤气、参集堂西谷明学 年静輯宽无一照雀一兰喜治集 、雄百爾年九第九頁竟初策 七労本宗三二た二二なな゙近期第 七㗢社教言年原巻年。代会酉

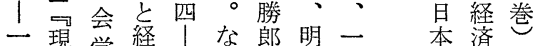

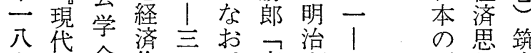
七仏会倫三克安形想摩 頁教編理三元西献 $\underline{0}$ 成患書 森講岩|頁論宗二頁采岩

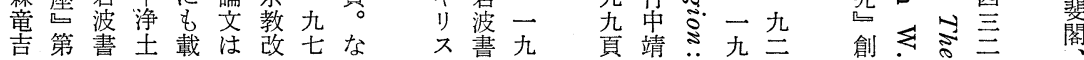

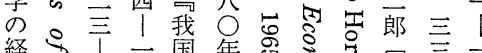

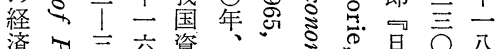

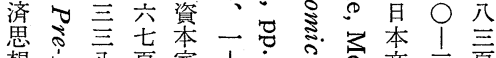

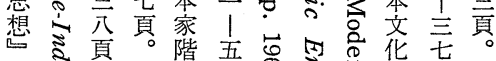

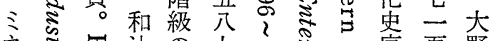

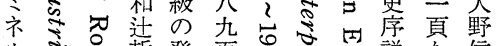
儿怘哲登頁总志鸟説な信

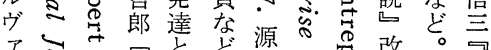

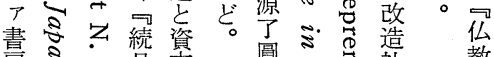

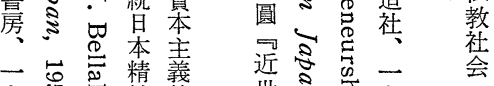

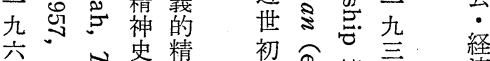

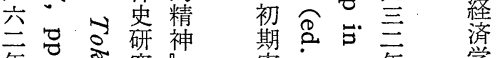

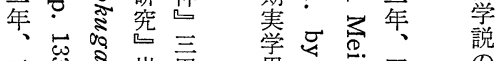
三 2 岕岩思思焉: 四研

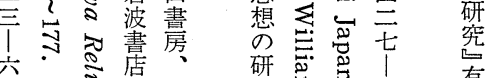

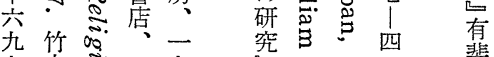




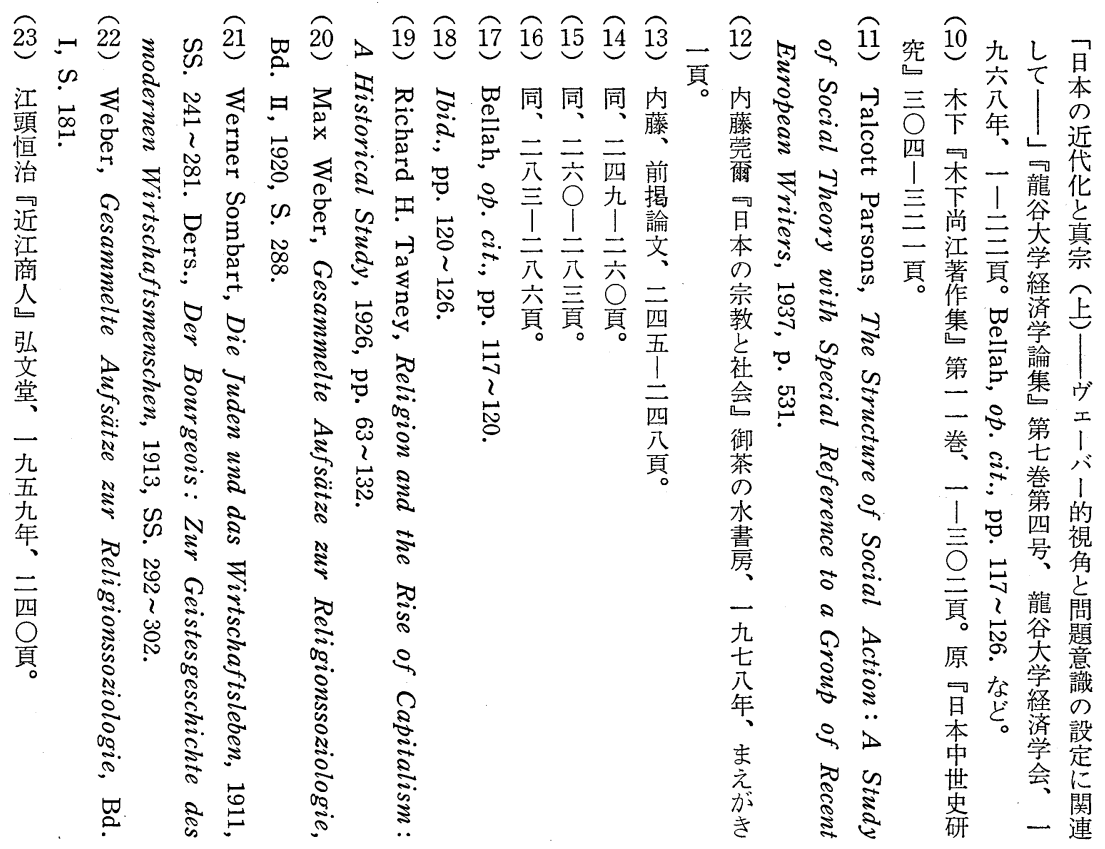




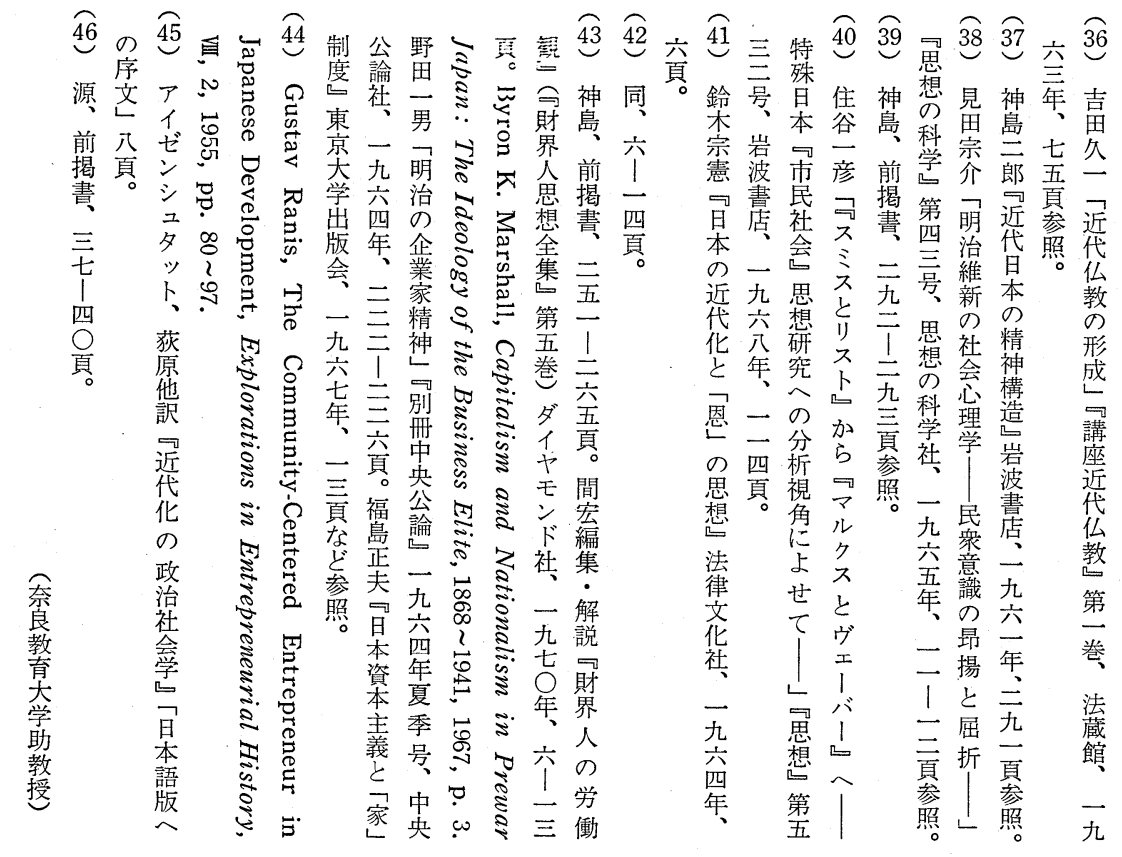


Zusammenhang des Jōdo-shinshū-Buddhismus mit der Modernisierung hoch ein, aber wenn man ihre Forschungen mit der Arbeit Max Webers vergleicht, stellen sich folgende zwei Probleme: Erstens ihr nicht hinrechendes Überlegen des Unterschieds $z$ wischen der japanischen und der europäischen Form der Geschichsentwicklung, und zweitens der Unterschied ihres Vergleiches, d.h. gegenüber Webers Untersuchung des Zusammenhangs zwischen Protestantismus und Industriekapital, betrachten sie den Zusammenhang des Jōdo-shinshūBuddhismus mit dem Handelskapial.

Im folgenden werden die Arbeiten von Max Weber selbst und Iichi Oguchi behandelt, die den Zusammenhang des Jödo-shishū-Buddhismus mit Japans Modernisierung als nicht so stark bewerten. Daraus ergeben sich folgende zwei Fragen, besonders wenn man auf dem von Max Weber angebahnten Weg weitergehen will: warum entstand in Japan anders als in Europa nicht der asketische Geist als eine persönliche innere Norm, und warum konnte trotzdem auch in Japan ein Arbeitsethos entstehen und die Kapitalisierung so intensiv vorangetrieben werden.

Schließlich kommt diese Abhandlung zu einer negativen Einschätzung gegen über der Auffassung, daß die Subjektivitätsbedingungen der japanischen Modernisierung in seinen Religionen (einschließlich des Jōdo-shinshūBuddhismus) liegen, und $\mathrm{da} \beta$ man die Gründe dafür viel mehr in den Bedingungen der äußeren Norm der schicksalsverbundenen Gemeinschaftsmitglieder des "ie*"-System bzw. der "Nation" finden kann.

* Das Wort " ie" bedeutet nicht nur eine "Familie", sondern auch eine Verkettung der über Generationen fortgesetzten Familiengruppen.

\section{The Transformation of the "keiyakuko" and the Process of the Reorganization in Rural Community}

- A monographic study of "Tsugihashi" in Miyagi prefecture -

\section{Ichizo Goto \\ Miyagi Furukawa-Jyoshi High School}

This article is presented with an intention of clarifying the transformation of the rural community after the World War II through a monographic study of the changes in life group (seikatsu gojo kankei) of the rural community.

In the concrete, the approach is mainly to be made as to what the internal reaction has been in the replacing process from 'keiyakuko' to 'kyodokai'. 
reciprocal gift-making. Reciprocal gift-making, called "exchange" by some exchange theorists, should be distinguished from exchange by the lack of the agreement characteristic of exchange. In the case of distrihution in the strict sense, each recipient receives a share of collectively-owned goods or goods none has yet owned. Distribution can be subdivided into three types: centralized distribution (i.e., each recipient receives the share the distributor has allotted to him), agreed distribution (i.e., each recipient receives his share by agreement with the other recipients), and unrestricted distribution (i.e., each recipient receives at his own discretion).

The processes of exchange, gift-making and distribution are examined from the perspective of a "Reward-Cost Postulate", rather than Exchange Theory. On the basis of empirical findings is posited a set of propositions, some examples of which are as follows.

(1) The parties' accurate knowledge of each other's preference tends to shorten the negotiation period that precedes the exchange.

(2) A's liking for B facilitates the occurrence of gift-making from A to $\mathrm{B}$.

(3) The outcome of centralized distribution tends to favor certain recipients, if (a) they are aware of how goods are distributed, and (b) they can exercise some control over the distributor's fate. etc.

\section{Die Japanische Modernisierung und der Jōdo-shinshū-Buddhismus}

- Einige Probleme im Zusammenhang mit dem Problembewußtsein und dem analytischen Blickwinkel Max Webers -

\section{Shin Ogasawara Pädagogische Hochschule Nara}

Von mehreren wissenschaftlichen Veröffentlichungen, die einen Zusammenhang zwischen Japans Modernisierung (sprich: Kapitalisierung) und seinen traditionellen Religionen $z \mathfrak{u}$ erforschen versuchen, behandelt die vorliegende kurze Abhandlung nur einige besondere Untersuchungen, die thematisch einen inneren Zusammenhang $z$ wischen der Modernisierung Japans, und dem Jōdo-shinshū-Buddhismus herzustellen versuchen.

Zunächst sollen die Versuche von Kanji Naitō und Robert N. Bellah kritisch in Betrachtung gezogen werden. Beide schätzen zwar den 